\title{
外傷性凝固障害におけるフィブリノゲン
}

早川峰司*

\section{Fibrinogen in trauma-associated coagulopathy}

Mineji HAYAKAWA

要約：フィブリノゲンはフィブリンの唯一の基質であるため，他に代償する 凝固因子がなく，止血のために不可欠な蛋白質である。このため，フィブリ ノゲン以外の凝固因子が潤沢に存在していてもフィブリノゲン自体が不足し ていれば適切な止血を得ることができない，重症外傷では，フィブリノゲン の低下が早期から生じており，フィブリノゲンの低下は，その後の大量出血 や生命予後の悪化と強く関係している。この重症外傷に扮けるフィブリ) ゲン低下の機序として，1)凝固活性化に伴う消費，(2)線溶六進に伴う分解， (3)輸液/輸血療法による希釈，が考えられている。重症外傷における抗線溶 薬の投与の有益性が報告されている。 フィブリノゲンの補充療法としては, 新鮮凍結血漿が中心となるが，フィブリノゲン濃縮製剤の有益性も検討され ている.

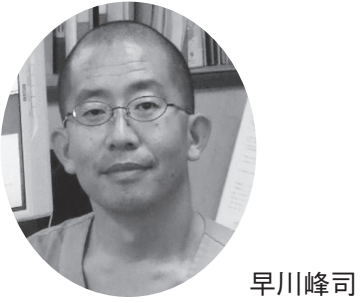

1997年 北海道大学医学部を卒 業 麻酔科研修を3年間 2000年〜 市立札幌病院 救命 救急センター 勤務 2003年〜 北海道大学病院 先 進急性期医療センター 勤務 2004年〜 北海道大学病院 先 進急性期医療センター 助教 現在に至る

Key words: coagulopathy, massive bleeding, fibrinolysis, fibrinogenolysis, disseminated intravascular coagulation

\section{1.はじめに}

フィブリノゲンは，血漿中に $150 \sim 450 \mathrm{mg} / \mathrm{dL}$ (約 $10 \mu \mathrm{mol} / \mathrm{L}$ ) 存在する止血のために不可欠な蛋白質で ある1-3)．フィブリンの唯一の基質であるため，他 に代償する凝固因子がなく，フィブリノゲン以外の 凝固因子が潤沢に存在していてもフィブリノゲンが 不足していれば，適切なフィブリン血栓の形成を得

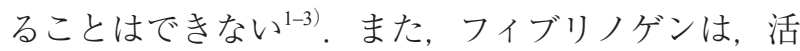
性化した血小板の GP IIb/IIa 受容体に結合すること により, von Willebrand 因子と同様の血小板凝集を 促進させる作用も有する ${ }^{1)}$ 。このため, 止血が重要 となる重症外傷の急性期には，フィブリノゲンの役 割は非常に重要なものとなる2,4).

\footnotetext{
*責任者連絡先：

北海道大学病院先進急性期医療センター

干 060-8648 札幌市北区北 14 条西 5 丁目

Tel: 011-706-7377, Fax: 011-706-7378

E-mail: mineji@dream.com
}

\section{2. 受傷直後のフィブリノゲン}

止血血栓の形成に重要な役割を有するフィブリノ ゲンであるが，重症外傷では，輸液による希釈の影 響のない受傷直後から，フィブリノゲンの低下を認 めることが報告されている ${ }^{5-11)}$ ，近年のヨーロッパの ガイドラインでは，重症外傷後に維持すべき止血関 連検査值の閾值として，フィブリノゲン值は 150 $200 \mathrm{mg} / \mathrm{dL}$ 以上, 血小板数は $50 \times 10^{9} / \mathrm{L}$ (頭部外傷合 併時は $\left.100 \times 10^{9} / \mathrm{L}\right)$ 以上, PT-INR は 1.5 以下などを 提示している ${ }^{12,13)}$ 。重症外傷患者に扮ける搬入時止 血関連検査では，フィブリノゲンは PT-INR や血小 板などの一般的な止血関連検査よりも高頻度にガイ ドラインで示されている閾值を超えて異常值を示す ことが報告されている $(\text { 図 } \mathbf{1})^{5)}$ ．また，このような 重症外傷における搬入時のフィブリノゲン值の低下 は，その後の大量出血や生命予後の悪化と強く関係 している ${ }^{6-8,14)}$. Inaba らは，260名の重症外傷患者 のうち， 54 名 $(21 \%)$ で搬入時のフィブリノゲンが 


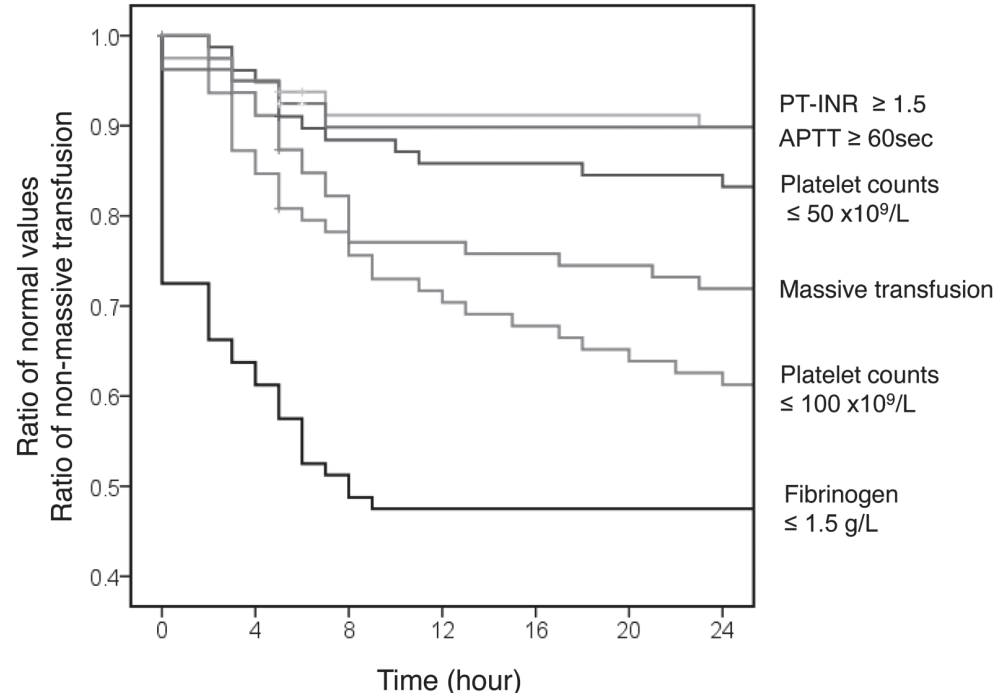

図 1 重症外傷における一般止血関連検査の異常值の頻度と夕イミング （文献 5 から引用）

フィブリノゲン值は，他の一般止血関連検査よりも早期かつ高頻度に異 常值を示している。

$100 \mathrm{mg} / \mathrm{dL}$ を下回っており, 114 名 (44\%)の患者で 100〜 $180 \mathrm{mg} / \mathrm{dL}$ を示していたと報告している ${ }^{8)}$. そ して, これらの患者群では, フィブリノゲン值の低 下に伴い, 外傷の重症度は増加し, 輸血量や死亡率 は段階的に増加していた 。 また，搬入時のフィブ リノゲンの低下は院内死亡の独立した予測因子であ ることも示されている ${ }^{8,14)}$.さらに，このフィブリ ノゲンの低下は, 病院搬入時よりも早いタイミング で生じており，多くの重症患者が受傷現場で既に凝 固障害を生じていたことが報告されている ${ }^{11)}$.

\section{3. フィブリノゲン低下の機序}

重症外傷症例でのフィブリノゲン值は, 他の凝固 因子や血小板よりも低下しやすく，止血機能異常の 原因となりやすいことが知られている ${ }^{5,11)}$. その機 序を整理すると，次の 3 つにまとめられる.

(1)凝固活性化に伴う消費

(2)線溶充進に伴う分解

(3)輸液/輸血療法による希釈

\section{(1)凝固活性化に伴う消費}

外傷直後, とくに組織損傷の著しい鈍的外傷の直 後では, 臓器/組織損傷を原因としたトロンビン産
生が充進していることが多く報告されている ${ }^{15-18)}$. Dunbarらは, 外傷受傷直後の患者の血漿検体では, 凝固活性化物質を添加しなくても自然にトロンビン 産生が生じることを，トロンビン生成試験をもちい て明示した(図 2 $)^{19,20)}$. これは, 外傷受傷直後には循 環血漿中を何らかの凝固活性化物質 (procoagulant) が流れていることを示す結果といえる。この凝固活 性化物質としては，外傷により損傷された臓器/組織 由来のマイクロパーティクル ${ }^{21)}$ やヒストン ${ }^{22)}$, ミト コンドリア DNA ${ }^{23)}$ な゙の damage associated molecular pattern(DAMPs)が考えられている.この DAMPs が引き起こす凝固の活性化により，フィブリノゲン がフィブリンに変換され，フィブリノゲンを中心と した凝固因子や血小板が消費性に減少を示す ${ }^{5-11}$. そして，形成されたフィブリンも後述の線溶反応の 光進により溶解され, D-dimer や fibrin/fibrinogen degradation products (FDP) となり高值を示す ${ }^{17,24,25)}$.

\section{(2)線溶六進に伴う分解}

外傷直後の凝固障害は, 線溶㐫進型播種性血管内 凝固症候群として認識されており線溶直進が特徵的 である ${ }^{26,27)}$ 。その線溶克進は, 外傷の受傷形態や, その後の呼吸/循環の状態により, 一次線溶と二次 線溶の 2 種類の線溶元進が様々な割合で混在してい 

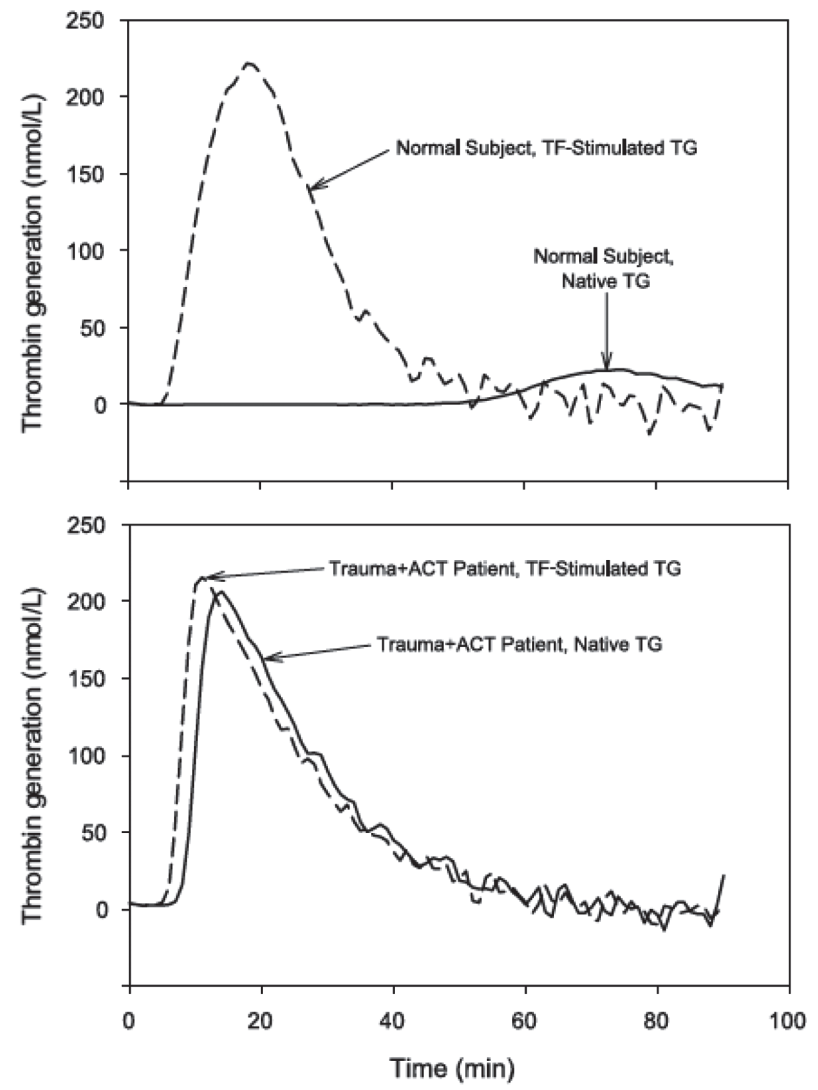

図 2 健常人と外傷患者におけるトロンビン生成試験の結 果(文献 19 から引用)

上段：健常者のトロンビン生成試験. 組織因子で刺激を するとトロンビン生成するが，刺激がないとトロンビン は生成されない.

下段：外傷患者のトロンビン生成試験。組織因子による刺 激がなくても，トロンビンが生成される。TF: tissue factor, TG: thrombin generation, ACT: acute coagulopathy of trauma

る、いずれの線溶充進でも, フィブリンだけではな くフィブリノゲンも分解されているため, フィブリ ノゲンの減少に拍車がかかっている ${ }^{17,24,25)}$.

一次線溶の立進 (acute release of t-PA)

全身の血管内皮細胞には，その細胞質内に存在す る Weibel Palade 小体内に tissue-plasminogen activator (t-PA) が貯蔵されている ${ }^{28,29)}$ 。この Weibel Palade 小体内の t-PA は, トロンビンや低酸素刺激 (ショッ ク)により，全身循環に放出される (acute release of $\mathrm{t}-\mathrm{PA})^{28,29)}$. 外傷直後の高度なショックにより acute release of t-PA が生じると，放出された t-PAにより血 漿中のプラスミノゲンがプラスミンへと活性化され,

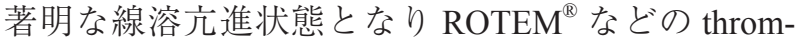
boelastometry で確認できるようになる ${ }^{30-34)}$ 。このよ うな ROTEM ${ }^{\circledR}$ で確認できるほどの著明な線溶立進 は，非常に高度なショックが引き金となっているた め, 予後は非常に悪( ${ }^{30-34)}$.

\section{二次線溶の无進}

ショック症状を呈さないような外傷症例でも, D-dimer や FDP の異常高值を認め, 凝固障害を呈す る症例は多い9, 17,24, 25,35). とくに, 頭部単独外傷では, 出血量が少なくショック状態を呈することが少ない が，D-dimer や FDP の異常高值を認め，凝固障害を 呈する症例は多い, ${ }^{95,36)}$. Kushimoto らは, 頭部単独 外傷症例で, 予後不良群は予後良好群と比較して, 搬入時の FDP $や$ fibrinogen degradation products (FgDP) が高值であり，フィブリノゲンが低下していること を示している9．また，FDPや FgDP は plasmin- $\alpha 2$ plasmin inhibitor complex と正の相関関係を示してお り，FDP P F DPP の上昇が，線溶㐫進の結果である ことが示されている9 . また, 別の検討では, 頭部 単独外傷症例における凝固障害は組織低かん流と直 接関係がないと結論付けている ${ }^{37)}$ 。これらの線溶立 進は, 前述の acute release of t-PAの影響ではなく, 組織損傷よる凝固充進に反応した二次線溶㐫進であ

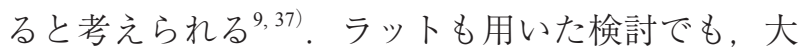
量の組織因子を投与することにより，組織低かん流 を来たすことなく，フィブリン分解とともにフィブ リノゲン分解の立進が生じており, 凝固障害を認め ていた ${ }^{38)}$.

\section{(3)輸液/輸血療法による希釈}

外傷症例では, 輸液/輸血療法の影響が小さい搬入 直後の段階でフィブリノゲンの低下をすでに認めて いるが, その後の輸液/輸血療法でも低下しやすいこ とが示されている ${ }^{39,40)}$. 定期手術患者における出血 に対し凝固因子を含まない赤血球輸血と晶質液で対 応した際の各凝固因子の低下の程度を観察した報告 では，フィブリノゲンが他の凝固因子よりも希釈に よる低下の速度が速いとの指摘がある ${ }^{39)}$ 。同様の結 果は, 豚を用いた動物実験でも確かめられている ${ }^{40)}$. 


\section{4. おわりに}

フィブリノゲンは止血に重要な因子であるにもか かわらず，外傷症例では低下しやすい因子でもある。 外傷症例におけるフィブリノゲン低下の中心である 線溶立進に対して, 早期の抗線溶薬(トラネキサム 酸)の投与が生命予後を改善することが大規模な無 作為化比較対照試験で示されている ${ }^{41)}$ 。 また, 既に 低下してしまった，もしくは低下しつつあるフィブ リノゲンに対する補充療法としては，新鮮凍結血漿 の投与が中心となる。外傷症例において，積極的な 新鮮凍結血漿の投与が生命予後を改善したという無 作為化比較対照試験が報告されている ${ }^{42)}$.さらに は, フィブリノゲン濃縮製剂の投与効果の検証も現 在進行中であり，その結果の報告が待たれる ${ }^{43)}$.

著者の利益相反 $(\mathrm{COI})$ の開示 :

共同研究費(旭化成ファーマ)

\section{文献}

1) Lowe GD, Rumley A, Mackie IJ: Plasma fibrinogen. Ann Clin Biochem 41: 430-440, 2004.

2) Sørensen B, Larsen OH, Rea CJ, Tang M, Foley JH, FengerEriksen C: Fibrinogen as a hemostatic agent. Semin Thromb Hemost 38: 268-273, 2012.

3) Mosesson MW: Fibrinogen and fibrin structure and functions. J Thromb Haemost 3: 1894-1904, 2005.

4) Counts RB, Haisch C, Simon TL, Maxwell NG, Heimbach DM, Carrico CJ: Hemostasis in massively transfused trauma patients. Ann Surg 190: 91-99, 1979.

5) Hayakawa M, Gando S, Ono Y, Wada T, Yanagida Y, Sawamura A: Fibrinogen level deteriorates before other routine coagulation parameters and massive transfusion in the early phase of severe trauma: a retrospective observational study. Semin Thromb Hemost 41: 35-42, 2015.

6) Hayakawa M, Maekawa K, Kushimoto S, Kato H, Sasaki J, Ogura H, Matauoka T, Uejima T, Morimura N, Ishikura H, Hagiwara A, Takeda M, Kaneko N, Saitoh D, Kudo D, Kanemura T, Shibusawa T, Furugori S, Nakamura Y, Shiraishi A, Murata K, Mayama G, Yaguchi A, Kim S, Takasu O, Nishiyama K: High D-dimer levels predict a poor outcome in patients with severe trauma, even with high fibrinogen levels on arrival: a multicenter retrospective study. Shock 45: 308314, 2016.

7) Schöchl H, Cotton B, Inaba K, Nienaber U, Fischer H, Voelckel W, Solomon C: FIBTEM provides early prediction of massive transfusion in trauma. Crit Care 15: R265, 2011.

8) Inaba K, Karamanos E, Lustenberger T, Schöchl H, Shulman I, Nelson J, Rhee P, Talving P, Lam L, Demetriades D: Impact of fibrinogen levels on outcomes after acute injury in patients requiring a massive transfusion. J Am Coll Surg 216: 290 297, 2013.

9) Kushimoto S, Shibata Y, Yamamoto Y: Implications of fibrinogenolysis in patients with closed head injury. J Neurotrauma 20: 357-363, 2003.

10) Schöchl H, Solomon C, Traintinger S, Nienaber U, TacacsTolnai A, Windhofer C, Bahrami S, Voelckel W: Thromboelastometric (ROTEM) findings in patients suffering from isolated severe traumatic brain injury. J Neurotrauma 28: 2033-2041, 2011.

11) Floccard B, Rugeri L, Faure A, Saint Denis M, Boyle EM, Peguet O, Levrat A, Guillaume C, Marcotte G, Vulliez A, Hautin E, David JS, Négrier C, Allaouchiche B: Early coagulopathy in trauma patients: an on-scene and hospital admission study. Injury 43: 26-32, 2012.

12) Rossaint R, Bouillon B, Cerny V, Coats TJ, Duranteau J, Fernández-Mondéjar E, Hunt BJ, Komadina R, Nardi G, Neugebauer E, Ozier Y, Riddez L, Schultz A, Stahel PF, Vincent JL, Spahn DR; Task Force for Advanced Bleeding Care in Trauma: Management of bleeding following major trauma: an updated European guideline. Crit Care 14: R52, 2010.

13) Spahn DR, Bouillon B, Cerny V, Coats TJ, Duranteau J, Fernández-Mondéjar E, Filipescu D, Hunt BJ, Komadina R, Nardi G, Neugebauer E, Ozier Y, Riddez L, Schultz A, Vincent JL, Rossaint R: Management of bleeding and coagulopathy following major trauma: an updated European guideline. Crit Care 17: R76, 2013.

14) Rourke C, Curry N, Khan S, Taylor R, Raza I, Davenport R, Stanworth S, Brohi K: Fibrinogen levels during trauma hemorrhage, response to replacement therapy, and association with patient outcomes. J Thromb Haemost 10: 1342-1351, 2012.

15) Gando S, Nakanishi Y, Kameue T, Nanzaki S: Soluble thrombomodulin increases in patients with disseminated intravascular coagulation and in those with multiple organ dysfunction syndrome after trauma: role of neutrophil elastase. J Trauma 39: 660-664, 1995.

16) Gando $S$, Kameue $T$, Matsuda $N$, Hayakawa M, Ishitani $T$, Morimoto Y, Kemmotsu O: Combined activation of coagulation and inflammation has an important role in multiple organ dysfunction and poor outcome after severe trauma. Thromb Haemost 88: 943-949, 2002.

17) Hayakawa M, Sawamura A, Gando S, Kubota N, Uegaki S, Shimojima H, Sugano M, Ieko M: Disseminated intravascular coagulation at an early phase of trauma is associated with consumption coagulopathy and excessive fibrinolysis both by plasmin and neutrophil elastase. Surgery 149: 221-230, 2011.

18) Engelman DT, Gabram SG, Allen L, Ens GE, Jacobs LM: Hypercoagulability following multiple trauma. World J Surg 20: 5-10, 1996.

19) Dunbar NM, Chandler WL: Thrombin generation in trauma patients. Transfusion 49: 2652-2660, 2009.

20) Chandler WL: Procoagulant activity in trauma patients. Am J Clin Pathol 134: 90-96, 2010.

21) Park MS, Owen BA, Ballinger BA, Sarr MG, Schiller HJ, Zietlow SP, Jenkins DH, Ereth MH, Owen WG, Heit JA: Quantification of hypercoagulable state after blunt trauma: 
microparticle and thrombin generation are increased relative to injury severity, while standard markers are not. Surgery 151: 831-836, 2012.

22) Abrams ST, Zhang N, Manson J, Liu T, Dart C, Baluwa F, Wang SS, Brohi K, Kipar A, Yu W, Wang G, Toh CH: Circulating histones are mediators of trauma-associated lung injury. Am J Respir Crit Care Med 187: 160-169, 2013.

23) Zhang Q, Raoof M, Chen Y, Sumi Y, Sursal T, Junger W, Brohi K, Itagaki K, Hauser CJ: Circulating mitochondrial DAMPs cause inflammatory responses to injury. Nature 464 : 104-107, 2010.

24）早川峰司, 和田剛志, 菅野正寛, 下嶋秀和, 上垣慎二, 澤村淳, 丸藤哲：鈍的外傷患者における FDP (fibrin/fibrinogen degradation products) 高值と大量出血の関連性. 日本救急医学会雑誌 21: 165-171, 2010.

25) Sawamura A, Hayakawa M, Gando S, Kubota N, Sugano M, Wada T, Katabami K: Disseminated intravascular coagulation with a fibrinolytic phenotype at an early phase of trauma predicts mortality. Thromb Res 124: 608-613, 2009.

26) Gando S, Hayakawa M: Pathophysiology of trauma-induced coagulopathy and management of critical bleeding requiring massive transfusion. Seminars in thrombosis and hemostasis, 2015 , in press.

27) Gando S, Otomo Y: Local hemostasis, immunothrombosis, and systemic disseminated intravascular coagulation in trauma and traumatic shock. Crit Care 19: 72, 2015.

28) Lowenstein CJ, Morrell CN, Yamakuchi M: Regulation of Weibel-Palade body exocytosis. Trends Cardiovasc Med 15: 302-308, 2005.

29) Kooistra T, Schrauwen Y, Arts J, Emeis JJ: Regulation of endothelial cell t-PA synthesis and release. Int J Hematol 59: 233-255, 1994.

30) Levrat A, Gros A, Rugeri L, Inaba K, Floccard B, Negrier C, David JS: Evaluation of rotation thrombelastography for the diagnosis of hyperfibrinolysis in trauma patients. Br J Anaesth 100: 792-797, 2008.

31) Kutcher ME, Cripps MW, McCreery RC, Crane IM, Greenberg MD, Cachola LM, Redick BJ, Nelson MF, Cohen MJ: Criteria for empiric treatment of hyperfibrinolysis after trauma. $\mathrm{J}$ Trauma Acute Care Surg 73: 87-93, 2012.

32) Theusinger OM, Wanner GA, Emmert MY, Billeter A, Eismon J, Seifert B, Simmen HP, Spahn DR, Baulig W: Hyperfibrinolysis diagnosed by rotational thromboelastometry (ROTEM) is associated with higher mortality in patients with severe trauma. Anesth Analg 113: 1003-1012, 2011.

33) Kashuk JL, Moore EE, Sawyer M, Wohlauer M, Pezold M, Barnett C, Biffl WL, Burlew CC, Johnson JL, Sauaia A: Primary fibrinolysis is integral in the pathogenesis of the acute coagulopathy of trauma. Ann Surg 252: 434-442; discussion 443-444, 2010.
34) Schöchl H, Frietsch T, Pavelka M, Jámbor C: Hyperfibrinolysis after major trauma: differential diagnosis of lysis patterns and prognostic value of thrombelastometry. J Trauma 67: 125-131, 2009.

35) Tian HL, Chen H, Wu BS, Cao HL, Xu T, Hu J, Wang G, Gao WW, Lin ZK, Chen SW: D-dimer as a predictor of progressive hemorrhagic injury in patients with traumatic brain injury: analysis of 194 cases. Neurosurg Rev 33: 359-365; discussion 65-66, 2010.

36) Goodnight SH, Kenoyer G, Rapaport SI, Patch MJ, Lee JA, Kurze T: Defibrination after brain-tissue destruction: A serious complication of head injury. N Engl J Med 290: 10431047, 1974.

37) Lustenberger $T$, Talving $P$, Kobayashi L, Barmparas G, Inaba K, Lam L, Branco BC, Demetriades D: Early coagulopathy after isolated severe traumatic brain injury: relationship with hypoperfusion challenged. J Trauma 69: 1410-1414, 2010.

38) Hayakawa M, Gando S, Ieko M, Honma Y, Homma T, Yanagida Y, Kubota N, Uegaki S, Sawamura A, Asakura H: Massive amounts of tissue factor induce fibrinogenolysis without tissue hypoperfusion in rats. Shock 39: 514-519, 2013.

39) Hiippala S: Replacement of massive blood loss. Vox Sang 74 Suppl 2: 399-407, 1998.

40) McLoughlin TM, Fontana JL, Alving B, Mongan PD, Bünger $\mathrm{R}$ : Profound normovolemic hemodilution: hemostatic effects in patients and in a porcine model. Anesth Analg 83: 459465, 1996.

41) CRASH-2 trial collaborators, Shakur H, Roberts I, Bautista R, Caballero J, Coats T, Dewan Y, El-Sayed H, Gogichaishvili T, Gupta S, Herrera J, Hunt B, Iribhogbe P, Izurieta M, Khamis H, Komolafe E, Marrero MA, Mejía-Mantilla J, Miranda J, Morales C, Olaomi O, Olldashi F, Perel P, Peto R, Ramana PV, Ravi RR, Yutthakasemsunt S: Effects of tranexamic acid on death, vascular occlusive events, and blood transfusion in trauma patients with significant haemorrhage (CRASH-2): a randomised, placebo-controlled trial. Lancet 376: 23-32, 2010.

42) Holcomb JB, Tilley BC, Baraniuk S, Fox EE, Wade CE, Podbielski JM, del Junco DJ, Brasel KJ, Bulger EM, Callcut RA, Cohen MJ, Cotton BA, Fabian TC, Inaba K, Kerby JD, Muskat P, O'Keeffe T, Rizoli S, Robinson BR, Scalea TM, Schreiber MA, Stein DM, Weinberg JA, Callum JL, Hess JR, Matijevic N, Miller CN, Pittet JF, Hoyt DB, Pearson GD, Leroux B, van Belle G; PROPPR Study Group: Transfusion of plasma, platelets, and red blood cells in a 1:1:1 vs a 1:1:2 ratio and mortality in patients with severe trauma: the PROPPR randomized clinical trial. JAMA 313: 471-482, 2015.

43) Maegele M, Zinser M, Schlimp C, Schöchl H, Fries D: Injectable hemostatic adjuncts in trauma: Fibrinogen and the FlinTIC study. J Trauma Acute Care Surg 78: S76-82, 2015. 